\title{
IMPLEMENTASI PROGRAM KERJASAMA ANTARA PERGURUAN TINGGI DENGAN DUNIA INDUSTRI
}

\author{
Dina Sugiyanti ${ }^{1}$, Didik Nurhadi ${ }^{2}$ \\ ${ }^{1}$ Dosen Jurusan Tadris Kimia FITK IAIN Walisongo \\ ${ }^{2}$ Dosen Jurusan Pendidikan Teknik Mesin Universitas Negeri \\ Malang
}

\begin{abstract}
Abstrak
Masalah utama pendidikan nasional adalah bagaimana upaya untuk memperbaiki mutu lulusan yang masih rendah. Hal ini antara lain ditandai oleh: (a) ketidaksiapan sebagian besar lulusan untuk memasuki dunia kerja, (b) rendahnya perolehan skor rata-rata ujian akhir pada hampir semua bidang studi $(<5,00)$, (c) proses pembelajaran di lembaga pendidikan umumnya belum berorientasi pada kompetensi yang dibutuhkan masyarakat pengguna (users), (d) substansi bidang studi belum menapak pada kebutuhan empirik sehingga menimbulkan penguasaan yang verbalistik, dan (e) ketidakseimbangan pertumbuhan pasar kerja dengan penambahan jumlah calon tenaga kerja dalam kualifikasi.

Banyak cara yang dapat ditempuh untuk meningkatkan mutu proses dan hasil pendidikan, salah satunya dengan model pendidikan kolaboratif. Model pendidikan kolaboratif yang dilakukan dengan mengoptimalkan kemitraan lembaga pendidikan dengan dunia bisnis dan industri maupun masyarakat pengguna lainnya secara lebih luas mampu meningkatkan mutu lulusan yang kompetitif. Dengan demikian, diharapkan lulusan lembaga pendidikan tersebut selain siap kerja juga siap menciptakan lapangan kerja bagi dirinya dan orang lain.
\end{abstract}

\section{Kata Kunci:}

Perguruan tinggi, industri, pembelajaran kolaboratif 


\section{PENDAHULUAN}

Peranan dan kedudukan lembaga pendidikan khususnya pendidikan tinggi menjadi penting dan strategis apabila dikaitkan dengan titik berat pembangunan nasional yaitu sektor ekonomi dan sumberdaya manusia. Melalui peningkatan peranan dan pembangunan dibidang pendidikan ini diwujudkan sumber daya manusia sebagai subyek pembangunan nasional yang memiliki wawasan luas dan tingkat keahlian profesional yang memadai. Sumber daya manusia seperti itu diharapkan mampu menggali, memanfaatkan, mengembangkan dan melestarikan potensi sumber daya alam dan manusia yang ada di daerah dalam persaingan di pasar global.

Hal ini sejalan prinsip penyelenggaraan pendidikan yang ada dalam Undang-undang Sistem Pendidikan Nasional Tahun 2003 pasal 4 ayat 6 yaitu pendidikan diselenggarakan dengan memberdayakan semua komponen masyarakat melalui peran serta dalam penyelenggaraan dan pengendalian mutu layanan pendidikan. Berbagai kendala cukup menjadikan permasalahan dalam pelaksanaan proses pembelajaran khususnya untuk pendidikan tinggi. Kendala yang dihadapi dalam penyelenggaraan pendidikan secara empiris antara lain: sumber daya manusia yang terbatas, sarana dan prasarana lembaga yang minim karena belum komitmennya pemerintah daerah dalam peningkatan pendidikan, kesadaran masyarakat tentang pendidikan masih minim, budaya masyarakat yang berbeda dengan budaya pendidikan, dan lainnya (Black, J. A. dan Champion, D. J, 1999).

Guna mengatasi permasalahan tersebut memang perlu adanya upaya atau langkah kreatif dari lembaga pendidikan dalam mengupayakan peningkatan mutu pendidikan khususnya lulusannya untuk mampu berkompetisi dalam dunia kerja. Salah satu strategi yang digunakan dalam meningkatkan mutu pembelajaran adalah dengan melakukan pembelajaran kolaborasi. Pembelajaran kolaborasi ini dilakukan dengan menggunakan sarana laboratorium, workshop dan peralatan perusahaan sebagai media pembelajaran (Sonhaji, 1993). Diharapkan dari pembelajaran kolaborasi ini akan terbentuk pola kesesuaian antara 
perguruan tinggi dengan industri pasangannya yang akan berdampak pada peningkatan prestasi belajar siswa.

\section{RUMUSAN MASALAH}

Berdasarkan latar belakang di atas, maka yang menjadi permasalahan dalam makalah ini adalah sebagai berikut:

1. Bagaimana model pembelajaran kolaboratif antara perguruan tinggi dengan dunia industri?

2. Bagaimana implementasi program kerjasama antara perguruan tinggi dengan dunia industri?

\section{TUJUAN}

Tujuan dari penulisan makalah ini adalah sebagai berikut:

1. Mengetahui bagaimana model pembelajaran kolaboratif antara perguruan tinggi dengan dunia industri

2. Mengetahui implementasi program kerjasama antara perguruan tinggi dengan dunia industri

\section{PEMBAHASAN}

\section{PENGERTIAN PEMBELAJARAN}

Pembelajaran adalah proses interaksi peserta didik dengan pendidik dan sumber belajar pada suatu lingkungan belajar (UU RI No. 20 Th 2003 Pasal 1). Dan pengalaman belajar yang paling efektif adalah apabila siswa/seseorang mengalami/berbuat secara langsung dan aktif dilingkungan belajarnya. Pemberian kesempatan yang luas bagi siswa untuk melihat, memegang, merasakan dan mengaktifkan lebih banyak indera yang dimilikinya serta mengekspresikan diri akan membangun pemahaman pengetahuan, perilaku dan keterampilannya. Oleh karena itu, tugas utama pendidik adalah mengkondisikan situasi pengalaman belajar yang dapat menstimulasi atau merangsang indera dan keingintahuan siswa. Hal lain yang perlu diperhatikan juga adalah pengetahuan dosen akan perkembangan psikologis siswa dan kurikulum dimana keduanya harus saling terkait (Arief Furchan, 1982). 
Dengan demikian, pendidik/dosen hendaknya menyiapkan kegiatan belajar mengajar yang melibatkan mental siswa secara aktif melalui beragam kegiatan, seperti kegiatan mengamati, bertanya/mempertanyakan, menjelaskan, berkomentar, mengajukan hipotesis, mengumpulkan data dan sejumlah kegiatan mental lainnya. Dosen hendaknya tidak memberikan bantuan secara dini dan hendaknya selalu menghargai usaha siswa meskipun hasilnya belum sempurna. Selain itu, dosen perlu mendorong siswa supaya siswa berbuat/berpikir lebih baik, misalnya melalui pengajuan pertanyaan menantang yang 'menggelitik' sikap ingin tahu dan sikap kreativitas siswa. Dengan cara ini, dosen selalu mengupayakan agar siswa terlatih dan terbiasa menjadi pelajar sepanjang hayat.

Dalam rangka peningkatan kualitas proses pembelajaran, perguruan tinggi perlu secara kreatif mengembangkan konsep-konsep pendidikan baru yang lebih komprehensif sekaligus kompetitif. Hal ini dapat dilakukan dengan pembaharuan metode pembelajaran yang lebih fleksibel, dengan penempatkan mahasiswa sebagai subyek (student-centered learning), dibandingkan sebagai obyek pendidikan. Konsep pendidikan juga perlu didesain untuk menumbuhkan semangat kewirausahaan dan peningkatan soft skills serta success skills, sehingga lulusan perguruan tinggi akan mempunyai karakter percaya diri yang tinggi, memiliki kearifan terhadap nilai-nilai sosial dan kultural bangsa, kemandirian serta jiwa kepemimpinan yang kuat (E. Mulyasa, 2003).

Perguruan tinggi harus mampu mengembangkan kurikulum yang holistik, sehingga proses pendidikan tinggi tidak hanya menekankan pengembangan potensi dan kecerdasan intelektual (IQ), tetapi juga kecerdasan emosional (EQ) dan spiritual (SQ) secara harmonis. Kurikulum holistik yang dimaksud harus dirancang dengan pendekatan yang kontekstual sehingga mampu memunculkan niche tanpa mengurangi sasaran keilmuan atau keterampilan pokok pada bidang keilmuan masing-masing (Hamalik Oemar, 2007).

Mengingat adanya disparitas kualitas calon mahasiswa, 
ketidakberimbang-an akses terhadap sumber-sumber informasi dan teknologi, serta tidak meratanya akses kerjasama pada perguruan tinggi unggulan, maka diseminasi kemampuan suatu perguruan tinggi kepada perguruan tinggi lain harus diupayakan. Upaya tersebut dapat dilakukan melalui pengembangan kerjasama pendidikan, pembentukan jejaring keilmuan (networking) atau penyelenggaraan distance learning yang berkualitas dan terencana.

\section{BENTUK-BENTUK PEMBELAJARAN KOLABORASI}

Model pembelajaran berupa perencanaan atau pola yang digunakan sebagai pedoman dalam perencanaan pembelajaran tuntorial dan suatu penentuan perangkat-perangkat pembelajaran termasuk di dalamnya buku-buku, film, kom-puter, dan lain-lain. Setiap model dan desain pembelajaran mengarahkan peserta didik untuk membantu sedemikian rupa sehingga tujuan dari pembelajaran akan tercapai (Trianto, 2007).Sudrajat (2008) menyebutkan bahwa model pembelajaran merupakan bentuk pembelajaran yang tergambar dari awal sampai akhir kegiatan yang disajikan secara khas oleh guru. Model pembelajaran merupakan bungkus atau bingkai dari penerapan: pendekatan, metode, dan strategi pembelajaran.

Pendekatan pembelajaran dapat diartikan sebagai titik tolak atau sudut pandang pengajar terhadap proses pembelajaran, yang merujuk pada pandangan tentang terjadinya suatu proses yang sifatnya masih sangat umum. Proses tadi mewadahi, menginsiprasi, menguatkan, dan melatari metode pembelajaran dengan cakupan teoretis tertentu. Pembelajaran mewadahi dua jenis pendekatan: (1) pembelajaran yang berorientasi atau berpusat pada siswa (student centered approach) dan (2) pembelajaran yang berorientasi atau berpusat pada guru (teacher centered approach) (Sudrajat, 2008).

Kemp dalam Senjaya (2008) mengemukakan bahwa strategi pembelajaran berupa suatu kegiatan pembelajaran yang harus dikerjakan guru dan siswa agar tujuan pembelajaran dapat dicapai secara efektif dan efisien. trategi pembelajaran mengandung 
makna perencanaan. Strategi pada dasarnya masih bersifat konseptual tentang keputusan-keputusan yang akan diambil dalam suatu pelaksanaan pembelajaran. Pembelajaran dapat dikelompokkan ke dalam dua bagian pula, berdasar: (1) exposition-discovery learning dan (2) group-individual learning (Rowntree dalam Senjaya (2008)). Strategi pembelajaran dapat dibedakan antara induktif dan deduktif ditinjau dari cara penyajian dan cara pengolahannya.

Metode Pembelajaran juga diartikan sebagai cara yang digunakan untuk mengimplementasikan rencana yang sudah disusun dalam bentuk kegiatan nyata dan praktis untuk mencapai tujuan pembelajaran. Beberapa metode pembelajaran yang dapat digunakan untuk mengimplementasikan strategi pembelajaran, di antaranya: (1) ceramah; (2) demonstrasi; (3) diskusi; (4) simulasi; (5) laboratorium; (6) pengalaman lapangan; (7) brainstorming; (8) debat, (9) simposium, dan sebagainya.

Arends (1997) menyatakan "The term teaching model refers to a particular approach to intruction that includes its goals, syntax, environment, and management system". Istilah model pengajaran mengarah pada suatu pendekatan pembelajaran tertentu termasuk: tujuan, sintaks, lingkungan, dan sistem pengelolaan.

Kardi dan Nur (2000) mengatakan bahwa istilah model pembelajaran mempunyai makna yang lebih luas dari pada strategi, metode atau prosedur pembelajaran. Model pembelajaran mempunyai ciri khusus yang tidak dimiliki oleh strategi, metode, ataupun prosedur. Model pembelajaran meliputi: (1) rasional teoritik logis yang disusun oleh para pencipta atau pengembangnya, (2) landasan pemikiran tentang apa dan bagaimana peserta didik belajar, (3) tingkah laku mengajar yang diperlukan agar model tersebut dapat dilaksanakan dengan berhasil, dan (4) lingkungan belajar yang diperlukan untuk mencapai pembelajaran itu.

Istilah model pembelajaran juga meliputi pendekatan suatu model pembelajaran yang luas dan menyeluruh. Contohnya pada model pembelajaran yang berdasarkan masalah, kelompok-kelompok kecil peserta didik bekerjasama memecahkan 
suatu masalah yang disepakati antara peserta didik dan pengajar. Seringkali peserta didik menggunakan beberapa keterampilan, prosedur pemecahan masalah dan berfikir kritis ketika menerapkan model pembelajaran tersebut. Model pembelajaran berdasarkan masalah dilandasi oleh teori belajar konstruktivis. Model pembelajaran ini dimulai dengan cara menyajikan permasalahan nyata yang penyelesaiannya membutuhkan kerjasama di antara para peserta didik. Pengajar dalam model pembelajaran ini memandu peserta didik mengurai cara pemecahan masalah menjadi tahapan-tahapan kegiatan. Pengajar memberikan contoh mengenai keterampilan dan strategi yang dibutuhkan supaya tugas-tugas tersebut dapat terselesaikan. Pengajar menciptakan suasana kelas yang fleksibel dan berorientasi pada upaya penyelidikan oleh peserta didik.

Model-model pembelajaran dapat diklasifikasikan berdasarkan tujuan pembelajarannya, meliputi sintaks (urutan pola) dan sifat lingkungan belajarnya. Pembelajaran langsung merupakan suatu pembelajaran yang baik bagi peserta didik untuk mempelajari keterampilan dasar seperti tabel perkalian atau untuk topik-topik yang banyak terkait dengan penggunakan peralatan.Hal ini sebagai contoh pengklasifikasian pembelajaran berdasarkan tujuan.

Tiap-tiap model pembelajaran membutuhkan sistem pengelolaan dan lingkungan belajar yang sedikit berbeda. Misalnya model pembelajaran kooperatif. Peserta didik perlu berkomunikasi satu sama lain, sedangkan pada model pembelajaran langsung peserta didik harus tenang dan memperhatikan pengajar.

Nieveen dalam Trianto (2007) mengatakan bahwa suatu model pembelajaran dikatakan baik jika memenuhi criteria: sahih, praktis, dan efektif. Aspek kesahihan model pembelajaran dikaitkan dengan dua hal, (1) apakah model yang dikembangkan tersebut didasarkan pada rasional teoritik yang kuat dan (2) apakah terdapat konsistensi internal dalam melaksanakan model pembelajaran tersebut.

Khabibah (2006) menyebutkan bahwa untuk melihat tingkat kelayakan suatu model pembelajaran dari aspek validasi dibu- 
tuhkan ahli dan praktisi untuk memvalidasi model pembelajaran yang dikembangkan.

Aspek kepraktisan hanya dapat dipenuhi jika: (1) para ahli dan praktisi menyatakan bahwa apa yang dikembangkan dapat diterapkan dan (2) kenyataan menunjukkan bahwa apa yang dikembangkan tersebut dapat diterapkan. Aspek keefektifan model pembelajaran dapat dilihat dari parameter: (1) ahli dan praktisi berdasarkan pengalaman menyatakan model tersebut efektif dan(2) model tersebut secara operasional memberikan hasil sesuai dengan yang diharapkan. Suatu perangkat pembelajaran untuk suatu topik tertentu yang sesuai dengan model pembelajaran yang dikembangkan diperlukan guna melihat keberhasilan aspek kepraktisan dan efektifitas model pembelajaran (Khabibah, 2007).

Ted Panitz dalam Trianto (2007) menyebutkan bahwa pembelajaran kolaboratif suatu filsafat personal, bukan sekedar teknik pembelajaran di kelas. Kolaborasi filsafat interaksi dan gaya hidup menjadikan kerjasama sebagai suatu struktur interaksi yang dirancang sedemikian rupa guna memudahkan usaha kolektif untuk mencapai tujuan bersama. Pada segala situasi dan ketika sejumlah orang berada dalam suatu kelompok, kolaborasi merupakan suatu cara untuk berhubungan dengan saling menghormati dan menghargai kemampuan dan sumbangan setiap anggota kelompok. Pembagian kewenangan dan penerimaan tanggung jawab di antara para anggota kelompok untuk melaksanakan tindakan kelompok terdapat di dalam kolaborasi. Konsensus yang terbina melalui kerjasama di antara anggota kelompok sebagai lawan dari kompetisi yang mengutamakan keunggulan individu merupakan pokok pikiran yang mendasari pembelajaran kolaboratif. Para praktisi pembelajaran kolaboratif memanfaatkan filsafat ini di: kelas, dalam rapat-rapat komite, dalam berbagai komunitas, dalam keluarga dan secara luas sebagai cara hidup dengan dan dalam berhubungan dengan sesama.

John Myers dalam Akhmad Sudrajat (2008) menjelaskan bahwa definisi collaboration berasal dari akar kata Latin dengan makna yang menitikberatkan proses kerjasama. Sedangkan jika 
kata cooperation, maka berfokus pada produk kerjasama itu. Sonhadji (2005) menyebutkan bahwa salah satu model pembelajaran kolaboratif yang efektif dilakukan antara lembaga pendidikan dengan industri adalah Mixing Model (Cooperative-Dual). Adapun indikator dalam implementasi model pembelajaran ini, yaitu: (1) paduan/manual yang rinci dan jelas, (2) pembagian tugas dan wewenang yang merata, (3) data yang akurat tentang dunia usaha/industri, (4) pemberdayaan kelembagaan yang ada, (5) komitmen dosen/pengajar, peserta didik, dan orang tua, (6) komunikasi yang baik semua pihak, (7) paket-paket pembelajaran yang tepat dan operasional, dan (8) format training plans, training agreement, serta monitoring dan evaluasi.

Arends (1997) juga menyebutkan bahwa tidak ada satu model pembelajaran yang paling baik di antara yang lainnya, karena masing-masing model dapat dirasakan baik, apabila telah diujicobakan untuk mengajar materi matakuliah tertentu. Beberapa model pembelajaran yang ada perlu diseleksi untuk mendapatkan model pembelajaran yang paling baik untuk mengajarkan suatu materi matakuliah tertentu.

Pemilihan suatu model pembelajaran harus memiliki pertimbangan-pertimbangan, antara lain: materi matakuliah, tingkat perkembangan kognitif mahasiswa, dan sarana dan prasarana yang tersedia, serta lingkungan yang kondusif. Sehingga tujuan pembelajaran yang telah ditetapkan dapat tercapai.

Menurut Miller dan Seller (1998) disebutkan bahwa bentukbentuk kerjasama lembaga pendidikan dengan dunia industri terdapat 3 (tiga) bentuk utama yaitu darmawisata, widyawisata ke pabrik dan praktikum.

Pada umumnya darmawisata ditunjukkan untuk mengadakan perjumpaan pertama dengan praktik kejuruan. Kegiatan ini dimaksudkan untuk memberikan orientasi mengenai sutu cabang industri. Waktunya sangat terbatas, kadang berlangsung hanya beberapa jam saja.

Widyawisata bertujuan untuk membawa mahasiswa/ peserta diklat kedunia industri untuk melakukan tugas-tugas terbatas, kadang-kadang juga berlangsung beberapa jam saja. 
Kegiatan ini berfungsi untuk memberikan wawasan realitas pabrik yang komplek, dan waktunya lebih lama dari pada darmawisata.

Sedangkan praktikum atau yang sering disebut praktik industri adalah kegiatan yang dilakukan oleh mahasiswa/ peserta diklat berupa praktik langsung pada dunia kerja yang nyata. Waktu untuk praktik industri bervariasi, diantaranya ada yang melakukan satu bulan, dua bulan, tiga bula, ada satu atau dua semester, tergantung dari kebutuhannya.

\section{PEMBELAJARAN KOLABORASI SEBAGAI IMPLEMEN- TASI PROGRAM KERJASAMA}

Pola kerjasama antara lembaga pendidikan dengan dunia industri telah dirumuskan oleh Depdikbud dengan istilah model pendidikan sistem ganda. Namun implementasinya tidak semudah seperti konsepnya, oleh karenanya model yang lain dengan model pembelajaran kolaborasi antara lembaga pendidikan dan industri pasangannya. Sehingga model pembelajaran kolaborasi ini merupakan implementasi kongkrit dari pelaksanaan kerjasama antara lembaga pendidikan dengan dunia industri (Judawati dan Priyono, 2000).

Menurut Ahmad Sonhadji (2005) menyatakan bahwa diantara sistem manajemen pemagangan atau praktik kerja industri yaitu school model, cooperative education, dual system model, dan market model yang paling efektif saat ini adalah mixing model (cooperative-dual). Untuk bentuk mixing model dapat digambarkan sebagai berikut.

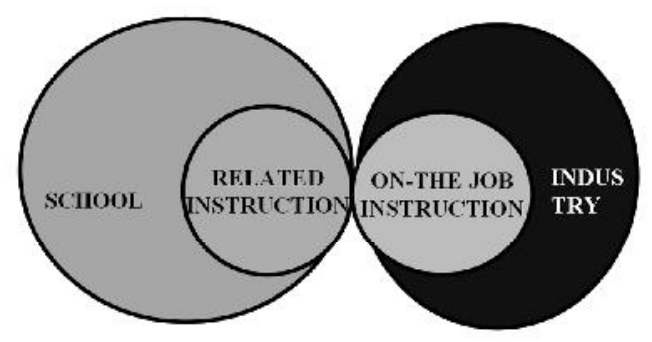

Gambar 1: Mixing model (cooperative - dual) 
Sementara beberapa alasan dipilihnya mixing model sebagai system kerjasama yang efektif adalah (1) pengalaman dalam dual system model sekolah dan industri sudah cukup akrab untuk berpasangan, (2) penerapan dual system banyak menghadapi kendala, (3) manajemen pada cooperative model lebih sederhana, dan (4) dari hasil penelitian menunjukkan keberhasilan cooperative model (Vidya Singh-Gupta dan Eileen Troutt-Ervin, 1997).

Untuk Management of Mixing model (cooperative-dual) dapat digambarkan seperti diagram berikut ini.

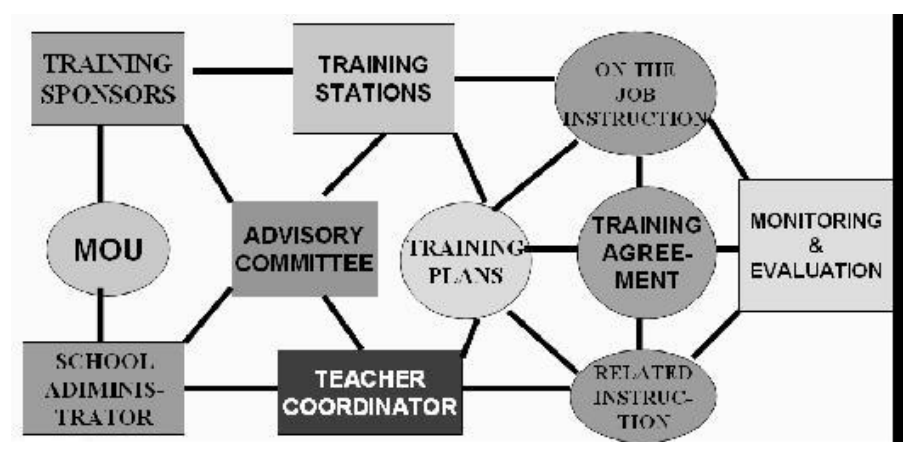

Gambar 2: Management of Mixing model (cooperative - dual)

Menurut Ahmad Sonhadji (2005) beberapa hal yang harus diperhatikan dalam implementasi management of mixing model adalah (1) pedoman/manual yang rinci \& jelas, (2) pembagian tugas dan wewenang yang merata, (3) data yang akurat tentang dunia usaha/industri, (4) pendayagunaan kelembagaan yang ada, (5) komitmen dosen/dosen, siswa, dan orang tua, (6) komunikasi yang baik semua pihak, (7) paket- paket pembelaaran yang tepat dan operasional, dan (8) format training plans, training agreement, serta monitoring \& evaluasi.

Pada lembaga pendidikan tinggi selain kegiatan belajar memang dilakukan di lingkungan sekolah juga dilakukan di lingkungan industri, sebagai tempat yang sama-sama digunakan untuk keperluan belajar. Karena keduanya memiliki karakteristik yang berbeda. Namun keduanya harus dipandang sebagai satu kesatuan yang utuh dalam membentuk kompetensi maha- 
siswa/ peserta diklat (Moedjianto, 1997), mengemukakan beberapa komponen-komponen penting dalam kerjasama, antara lain:

\section{Kelembagaan}

Dilihat dari segi kelembangaan pembelajaran kolaborasi ini terdiri dari 2 (dua) sub sistem yaitu sub sistem pembelajaran di industri dan sub sistem pembelajaran dikampus.

\section{Kurikulum}

Kurikulum di lembaga pendidikan tinggi dirancang secara komprehensif yang meliputi semua kegiatan pembelajaran. Sedangkan kurikulum yang ada di industri hanya berupa tuntutan praktik (training guideslines), yang jauh lebih sederhana dan lebih praktis dari pada kurikulum lembaga pendidikan.

\section{Materi pembelajaran}

Materi lembaga pendidikan lebih ditekankan pada pembelajaran teori-teori tinggi, sedangkan materi di industri lebih ditekankan pada praktik kerja tetapi berkaitan dengan teori-teori yang dipelajari di lembaga pendidikan. Dengan demikian lembaga pendidikan harus mampu menggunakan dunia kerja sebagai pijakan dalam perencanaan kurikulum, sehingga pembelajaran di lembaga pendidikan terintegrasi dengan pembelajaran praktik yang dilakukan di industri.

\section{Strategi mengajar}

Kegiatan pembelajaran yang dilakukan di lembaga pendidikan lebih sistematis karena pelajaran telah disusun secara sistematis berdasarkan kaidah-kaidah teori pembelajaran. Sedangkan pembelajaran di industri lebih menerapkan pada proses pembelajaran keterampilan kerja tertentu (Wena, 1993).

\section{Pengajar}

Di lembaga pendidikan dosen/dosenlah yang bertanggung jawab terhadap program pelaksanaan pembelajaran. Sedangkan 
di industri pembelajaran praktik sepenuhnya menjadi tanggung jawab instruktur. Sebagai tenaga pengajar praktik instruktur seyogyanya memahami dan mampu mempraktikkan metodemetode pembelajaran dalam kegiatan pembelajaran praktik di industri. Dengan demikian pembelajaran praktik kerja di industri betul-betul dapat meningkatkan kualitas kemampuan kompetensi mahasiswa/peserta diklat.

\section{Tempat Kerja}

Belajar di lembaga pendidikan sebagaian besar dilakukan di ruang kelas, sedangkan belajar di industri hampir seluruhnya dilakukan di laboratorium. Adanya perbedaan tempat belajar ini tentu pula akan mempengaruhi situasi pembelajaran. Oleh karena itu ketarkaitan yang selaras dan serasi antara kedua tempat belajar seyogyanya diciptakan. Dengan demikian proses pembelajaran pada kedua tempat tesebut dapat dilakukan secara optimal.

\section{KESIMPULAN}

Berdasarkan hasil pembahasan, kesimpulan yang diperoleh dalam makalah ini adalah sebagai berikut:

1. Bentuk-bentuk kerjasama antara perguruan tinggi dengan dunia industri secara umum meliputi tiga bentuk utama, yaitu darmawisata (berkunjung dan melihat-lihat), widyawisata (perjalanan ke luar (daerah, kampus, industri) dalam rangka kunjungan studi (biasanya berombongan) dalam rangka menambah ilmu pengetahuan, dan praktikum (kegiatan teori dilakukan di kampus sedangkan kegiatan praktikum dilakukan di industri).

2. Implementasi program kerjasama antara perguruan tinggi dengan dunia industri yang paling sering yaitu menggunakan mixing model (cooperative-dual) antara perguruan tinggi dengan industri. Pada kegiatan ini, kegiatan pembelajaran selain dilakukan di lingkungan kampus juga di lingkungan industri sehingga peserta didik dapat secara langsung melihat/mempraktekkan teori yang mereka peroleh. 


\section{DAFTAR PUSTAKA}

Arikunto, S. 1993. Prosedur Penelitian Suatu Pendekatan Praktek. Jakarta: Rineka Cipta

Ary, D, Jacobs, L.C., \& Razavich. 1982. Pengantar Penelitian Pendidikan. Terjemahan oleh Arief Furchan. Surabaya: Usaha Nasional

Black, J. A. \& Champion, D. J. 1999. Metode dan Masalah Penelitian Sosial. Bandung: PT. Refika Aditama

Eddy Sutadji dalam Jurnal Ilmu Pendidikan, Tahun 27, Nomor 2, Juli 2000 Hal. 149-157 yang Berjudul Pengembangan Modul Pembelajaran Individual untuk Meningkatkan Kualitas dan Hasil Pembelajaran dalam Matakualiah Pengetahuan Bahan. Malang: UM Malang

E. Mulyasa. 2003. Manajemen Berbasis Sekolah Konsep Strategi dan Implementasi. Bandung: PT. Remaja Rosdakarya

Hamalik Oemar. 2007. Dasar-dasar Pengembangan Kurikulum. Bandung: PT. Remaja Rosdakarya

J. P. Miller and W. Seller. 1998. Curricullum: Perspectives and Practice. Toronto. Copp Clark Pitman Ltd.

Judawati dan Priyono. 2000. Model Pendidikan Sistem Ganda: Studi Kasus Pelaksanaan Pengajaran Praktik Profesi Ke- 
juruan di PT. PAL Surabaya. Malang: Lembaga Penelitian Universitas Negeri Malang

Moedjianto dalam Jurnal Ilmu Pendidikan, Agustus 1997 Jilid 4, Nomor 3, Hal. 139-149 yang Berjudul Peningkatan Mutu Lulusan STM Melalui Pendidikan Sistem Ganda. Malang: UM Malang

Sanjaya, Wira. 2005. Pembelajaran dalam Implementasi Kurikulum Berbasis Kompetensi. Bandung: Kencana

Sa'dun Akbar dalam Jurnal Ilmu Pendidikan, November 1997 Jilid 4, Nomor 4, Hal. 197-205 yang Berjudul Kemitraan Sekolah Dengan Dunia Kerja: Pengembangan Karir Pada Sekolah Lanjutan di Jepang dan Indonesia. Malang: UM Malang

Sonhadji, Ahmad. 2005. Bahan-Bahan Perkuliahan Landasan Pendidikan Kejuruan. Program Pasca Sarjana Universitas Negeri Malang: Malang

Syafrudie, Haris A., dan Pribadi. 1999. Peran Institusi Pasangan Dalam Pelaksanaan Sistem Ganda. Malang: Lembaga Penelitian UM Malang

Vidya Singh-Gupta dan Eileen Troutt-Ervin. 1997. Assessment Of Workplace Writing And Incorporation Into Curriculum. (Online) Vol. 13, No. 2.

Usep Kustiawan dan Wahyu Sakti Gunawan Irianto dalam Jurnal Ilmu Pendidikan, Tahun 26, Nomor 2, Juli 1999 Hal. 162-169 yang Berjudul Relevansi Program Pendidikan SMK dengan Kebutuhan Dunia Kerja. Malang: UM.

Wena, M., dkk. 1994. Pola Pelaksanaan Program Pengajaran Praktik Industri Pada Sekolah Teknologi Menengah di Kotamadya Malang. Malang: P3T UM. 